\title{
Startup and Performance Stability of a Nitritation-Anammox Reactor Using Granular Sludge
}

\author{
Bolin Li*, Wenqin Zhang, Xueping Yan, Xin Huang, Jiangtao Li, Ye Li \\ School of Resources and Environmental Engineering, Wuhan University of Technology, \\ Wuhan 430070, PR China
}

Received: 6 May 2016

Accepted: 6 August 2016

\begin{abstract}
A nitritation-anammox single-stage autotrophic nitrogen-removal system was started and achieved stable, efficient operation. The startup process occurred in three stages: aerobic granulation, nitritation regulation, and autotrophic nitrogen removal. Granular sludge was successfully incubated after $57 \mathrm{~d}$ of acclimation. Through an operating strategy of gradual reduction in organic loading and an increase in ammonia nitrogen loading, stable nitritation was successfully achieved (average $\mathrm{NH}_{4}^{+}-\mathrm{N} / \mathrm{NO}_{2}$ ratio maintained at 1.32) Nitritation was coupled with anammox to achieve autotrophic nitrogen removal. The nitrogen loading rate was increased to $0.3 \mathrm{kgN} /\left(\mathrm{m}^{3} \bullet \mathrm{d}\right)$ and the removal rate reached $0.26 \mathrm{kgN} /\left(\mathrm{m}^{3} \bullet \mathrm{d}\right)$ after $50 \mathrm{~d}$ of operation. Test results showed that during the autotrophic nitrogen removal stage, anaerobic ammonia-oxidizing bacteria were considerably enriched, and that there was an organic balance between these and ammonia-oxidizing bacteria in the system.
\end{abstract}

Keywords: nitrogen removal, nitritation-anammox, stability, granular

\section{Introduction}

The nitritation-anammox single-stage autotrophic nitrogen-removal process has the potential for broad application in the treatment of wastewater with a low carbon/nitrogen ratio [1-2]. In existing technologies, nitritation and its coupling with anammox are rate-limiting steps in the whole process and are critical breakthrough points for increasing the processing capacity [3-5].

The key to achieving an effective nitritation process is to enrich ammonia-oxidizing bacteria (AOB) while

*e-mail: bolly1221@163.com inhibiting nitrite oxidizing bacteria (NOB). This enables $\mathrm{AOB}$ to have a competitive advantage and to achieve nitrite accumulation. Researchers have conducted numerous studies on ways to achieve nitritation, and have achieved nitrite accumulation by controlling one or more parameters, e.g., pH, dissolved oxygen (DO), free ammonia (FA), or free nitrous acid (FNA) [6-8]. However, NOB are highly adaptive and gradually resume their activity after the system has operated for a certain period. This makes it difficult to maintain long-term stability of the nitritation process.

DO is a critical factor used to achieve efficient and stable operation of the single-stage reactor. Low DO has a reversible inhibitory effect on anammox, whereas the inhibitory effect of high DO is irreversible [9-10]. Liu 
[11] and Vlaeminck et al. [12] controlled DO within a low range $(0.2-1.0 \mathrm{mg} / \mathrm{L})$ to facilitate the anammox process. However, it is very difficult to harmonize the contradictory DO demands of AOB and anaerobic ammonia-oxidizing bacteria (AAOB). Stable nitrite accumulation is essential to the operation of the autotrophic nitrogen removal system. In view of the aforesaid contradictory DO demands, Persson [8] and Gilbert et al. [13] achieved sludge granulation to enable a gradient distribution of DO in the granules. This led to the formation of aerobic and anaerobic microenvironments on the surface and in the interior, respectively, providing suitable dissolved oxygen conditions for symplastic growth of AOB and AAOB.

Tests proved that a gradient distribution of DO in granules simultaneously satisfied the antagonistic DO demands of $\mathrm{AOB}$ and $\mathrm{AAOB}$ while maintaining large amounts of biomass. However, because AAOB grows at an especially slow rate, adjusting the control parameters usually has an impact on the quantities and structures of microflora in the system. This can disrupt the microflora balance within the granular sludge, which is more difficult to restore than in flocculent sludge [14]. Consequently, the autotrophic nitrogen removal system would fail to maintain efficient and stable performance of nitrogen removal. Therefore, stricter requirements must be imposed on control of the operating parameters, such as loading, $\mathrm{pH}$, and DO. To date, there are no effective control strategies for such parameters.

This study focuses on a stable startup process and operating strategy of a single-stage autotrophic nitrogenremoval system. Regular flocculent-activated sludge was inoculated and rapidly granulated in an SBR reactor under non-real-time control conditions. Based on the characteristics of ammonia nitrogen consumption and nitrite nitrogen accumulation, a control method for parameters (DO and $\mathrm{pH}$ ) was established to achieve stable nitritation. Nitritation was coupled with the anammox process, and a control strategy for the singlestage autotrophic nitrogen removal system was proposed according to the differences in physiological properties among AOB, AAOB, and NOB. Based on this control strategy, stable operation of the single-stage autotrophic nitrogen-removal system was achieved, and the advantages of granule-enriched anammox biomass for the nitrogenremoval system will be discussed.

\section{Material and Methods}

\section{Reactor and Operational Strategy}

The SBR reactor was made of acrylic resin and had a working volume of $2.5 \mathrm{~L}$, and a height/diameter ratio of 2.7. The exchange ratio $\left(\mathrm{V}_{\text {Effluent }} / \mathrm{V}_{\text {Reactor }}\right)$ was fixed and maintained at 0.5 . During the experiment, the reaction temperature was kept near $25-30^{\circ} \mathrm{C}$. The aeration rate was controlled by a gas rotameter. An overhead mechanical stirrer was used in the reactor at a fixed speed of $100 \mathrm{r} / \mathrm{min}$.
The SBR was inoculated with $1.5 \mathrm{~L}$ of activated sludge collected from the Tangxunhu domestic sewage treatment plant in Wuhan, Hubei. The mixed liquid suspended solids (MLSS) value of the seeded sludge was 8-9 g/L.

Synthetic wastewater was used as influent in this study. The $\mathrm{pH}$ was controlled (7.8-8.2) by dosing with $\mathrm{NaHCO}_{3}$. The synthetic wastewater was supplemented with mineral medium. We used synthetic medium containing COD (300 mg/L), $\mathrm{NH}_{4}^{+}-\mathrm{N}(20 \mathrm{mg} / \mathrm{L}), \mathrm{TP}(5 \mathrm{mg} / \mathrm{L}), \mathrm{KH}_{2} \mathrm{PO}_{4}$ $(0.025 \mathrm{~g} / \mathrm{L}), \mathrm{CaCl}_{2} \cdot 2 \mathrm{H}_{2} \mathrm{O}(0.3 \mathrm{~g} / \mathrm{L}), \mathrm{MgSO}_{4}(0.2 \mathrm{~g} / \mathrm{L})$, and $\mathrm{FeSO}_{4}(0.0065 \mathrm{~g} / \mathrm{L})$, and $1 \mathrm{~mL} / \mathrm{L}$ trace element solution (as described in Wei et al., 2015) [15]. The $\mathrm{NH}_{4}^{+}-\mathrm{N}$ concentration was increased to $200 \mathrm{mg} / \mathrm{L}$ to develop the nitrification process, and COD gradually was reduced to zero during this process.

\section{Analysis Methods}

The $\mathrm{pH}$, DO, and ORP parameters were measured with a portable and recordable probe (HACH, HQ40d). Measurements of ammonium, nitrite, nitrate, SS, and VSS were performed using standard methods (APHA 2005) [16]. The particle size distribution in random samples of granular sludge from the reactor was analyzed using a laser particle-size analyzer (Mastersizer 2000, Melvin British Company). Color photomicrographs (NIKON Mia2000 E200-F, Japan) were used for observation of sludge morphology.

\section{Quantitative PCR}

A quantitative PCR system (Agilent Technologies, USA) was used to determine the distributions (in triplicate) of microbes in the SBR reactor. The gene sequences of $\mathrm{AOB}, \mathrm{NOB}, \mathrm{AAOB}$, and DNF rRNA were tested as described by Persson et al. [8].

\section{Results and Discussion}

\section{Aerobic Granulation Process}

\section{Strategies for Sludge Granulation}

We found that when the organic loading was high, partial filamentous bacteria in the sludge served as the framework for granulation, thereby accelerating the formation of granules [17]. In this study, within $17 \mathrm{~d}$ after startup of the SBR system, organic loading was maintained at $2.0 \mathrm{~kg} \mathrm{COD} /\left(\mathrm{m}^{3} \cdot \mathrm{d}\right)$, which facilitated the formation of microbial aggregates, and COD removal efficiency was maintained at $90 \%$ or above (Fig. 1). On Day 17 when the sludge expanded due to aeration failure, the organic loading was down-regulated to $1.2 \mathrm{~kg} \mathrm{COD} /\left(\mathrm{m}^{3} \bullet \mathrm{d}\right)$, after which point the system gradually resumed. Organic loading was maintained at this level during the subsequent incubation process.

The sedimentation time for the sludge in the reactor was gradually reduced from an initial $20 \mathrm{~min}$ to $5 \mathrm{~min}$. 


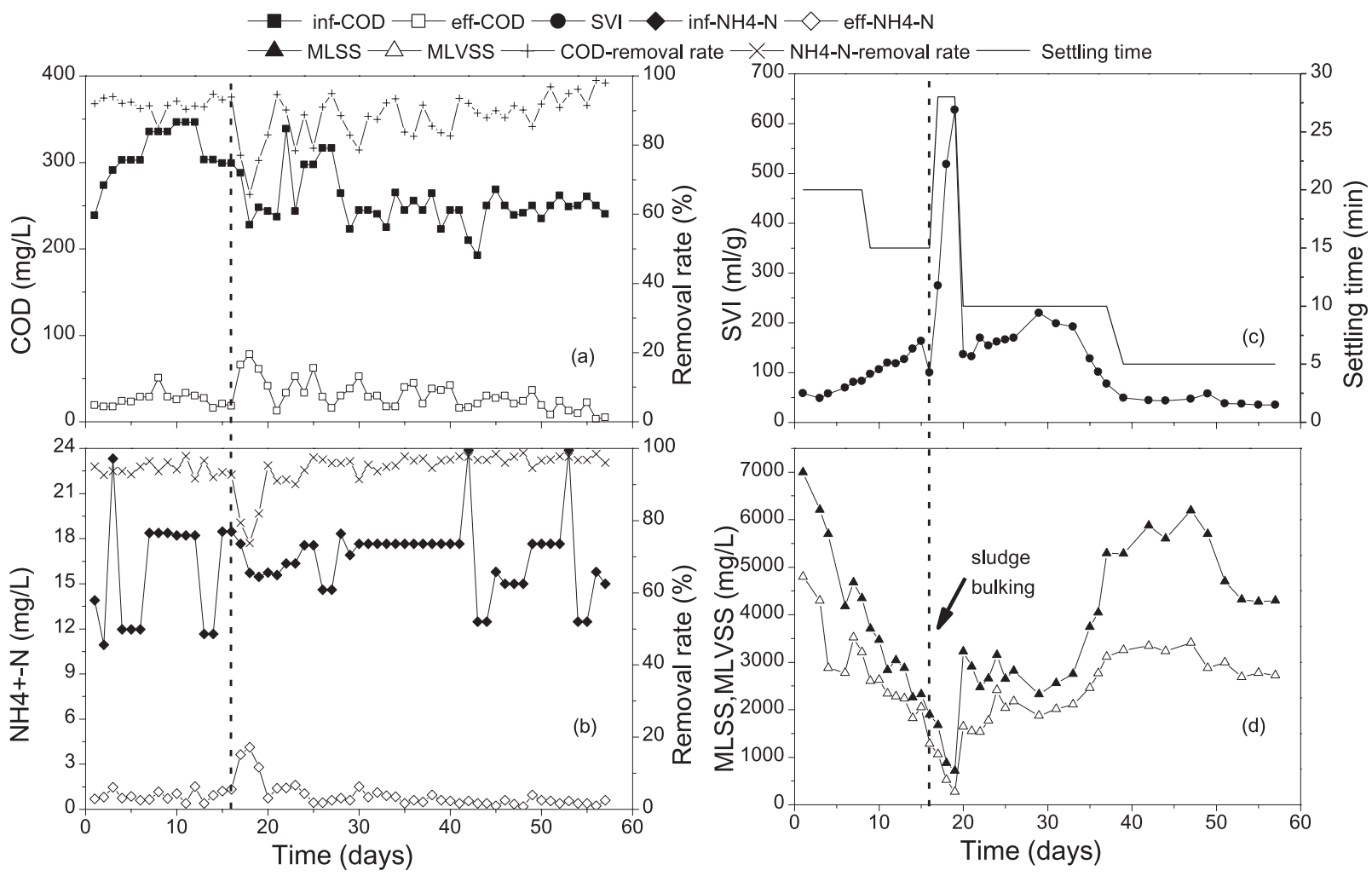

Fig. 1. Performance of the SBR system in the aerobic granulation stage.

The hydraulic screening action not only eliminated the dispersed, flocculent sludge from the reaction system, improved the systemic sedimentation properties (Fig. 1), and promoted the formation of the granular sludge, but it also stimulated changes in cell surface properties that facilitated the formation of biological flocs [18], thereby further promoting sludge granulation.

According to the study results of Zheng and Kenji Furukawa et al. [19-20], a shorter reaction cycle could lead to more frequent discharge of cells. Moreover, the hydraulic screening action enabled microorganisms with excellent sedimentation properties to remain in the system, and created suitable growth conditions for sludge granules. Within 1-10 d, the hydraulic retention time (HRT) was set at $8 \mathrm{~h}$. Excessive aeration resulted in serious degradation of organic components into inorganic compounds, so the HRT was adjusted to $6 \mathrm{~h}$, after which the MLSS in the system sustained a steady increase.

As shown in Fig. 1, during days 1-17 the system operated continuously with stable COD and ammonia-nitrogenremoval efficiency, both of which were maintained at $90 \%$ or above. During the sludge expansion stage, when the removal efficiencies started dropping, the aeration rate was adjusted to $0.6 \mathrm{~L} / \mathrm{min}$, DO was maintained at $1.5 \mathrm{mg} / \mathrm{L}$, the effluent exchange ratio was reduced, and fresh sludge was replenished expediently. Afterward, the SVI of the system was maintained at $170 \mathrm{~mL} / \mathrm{g}$ or below, sludge expansion was obviously alleviated, and MLSS quickly resumed a normal level of 2,600-3,200 $\mathrm{mg} / \mathrm{L}$. The reactor resumed stable removal efficiency on Day 28 .

\section{Sludge Morphology}

The SBR was operated for nearly two months under aerobic conditions for sludge granulation. The MLSS of the seeding sludge decreased from $8,000 \mathrm{mg} / \mathrm{L}$ to $6,980 \mathrm{mg} / \mathrm{L}$ after $7 \mathrm{~d}$ acclimation. Some tiny dark brown granules could be observed during stable operation. After sludge expansion on Day 17, the MLSS abruptly declined to $1,900 \mathrm{mg} / \mathrm{L}$ and the sludge appeared loose. On Day 28, the system gradually recovered and the sludge resumed its previous morphology (grayish black, small granules). On Day 57 the sludge had a more compact, dense structure with distinct granular boundaries (Fig. 2).

At the initial stage, the average particle size of the system was $97.478 \mu \mathrm{m}$. After $57 \mathrm{~d}$ of operation, the average particle size increased to $308.214 \mu \mathrm{m}$. It is widely accepted that if the proportion of granules $>200 \mu \mathrm{m}$ is more than $10 \%$, then the sludge has been successfully granulated [21]. On Day 49, more than $69 \%$ of the sludge granules in the system were greater than $200 \mu \mathrm{m}$, indicating successful aerobic sludge granulation in the reaction system.

\section{The Achievement of Partial Nitrification}

The saturation constant for oxygen is $0.2-0.4 \mathrm{mg} / \mathrm{L}$ for $\mathrm{AOB}$ and $1.2-1.5 \mathrm{mg} / \mathrm{L}$ for NOB [22]. This indicates that under low $\mathrm{DO}, \mathrm{AOB}$ grew faster than $\mathrm{NOB}$, so $\mathrm{AOB}$ could be enriched by the optimization of operating conditions. To investigate the feasibility of achieving stable nitritation in the SBR through DO control and the stability of the nitritation process, from Day 62 to 83 (Stage I) the aeration 

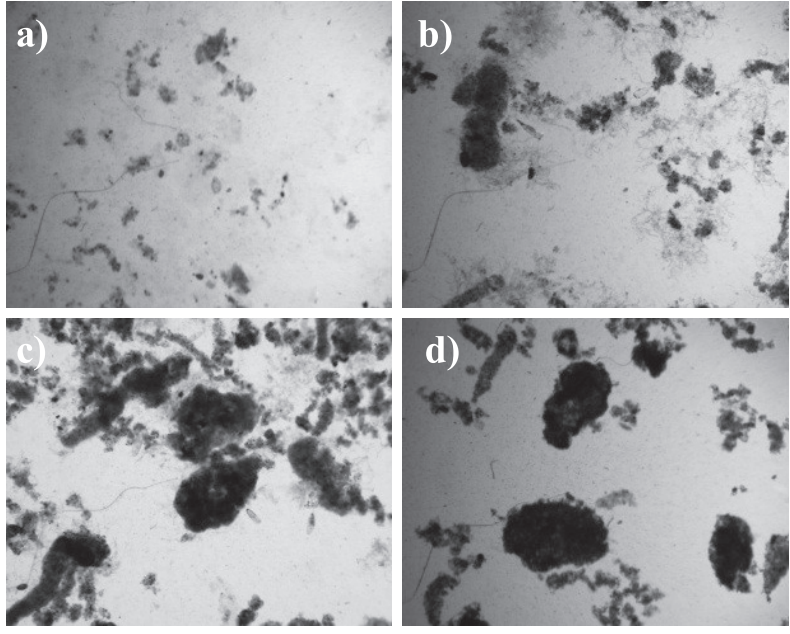

Fig. 2. Optical microscope photographs (40×): a) $1 \mathrm{~d}$ after seeding, b) $10 \mathrm{~d}$ after seeding, c) $35 \mathrm{~d}$ after seeding, d) $56 \mathrm{~d}$ after seeding.

rate was maintained at $0.4 \pm 0.1 \mathrm{~L} / \mathrm{min}$. Under the fixed oxygen supply mode, COD gradually decreased from 220 to $110 \mathrm{mg} / \mathrm{L}$ and the reactor exhibited excellent nitritation performance, so the influent $\mathrm{NH}_{4}^{+}-\mathrm{N}$ concentration was increased gradually from 30 to $70 \mathrm{mg} / \mathrm{L}$ (Fig. 3).

From Day 84-123 (Stage II), the influent $\mathrm{NH}_{4}^{+}-\mathrm{N}$ concentration was increased to $100 \mathrm{mg} / \mathrm{L}$, while COD decreased to zero. At a fixed aeration rate, as $\mathrm{NH}_{4}^{+}-\mathrm{N}$ was gradually consumed, the nitritation reaction slowed down due to reduced substrate concentration. As the DO level required for nitration was lower than that for nitritation, the DO level in the system quickly increased and the nitrogen removal rate of the reactor declined. Thereafter, nitrite oxidation occurred, leading to reduced concentration of accumulated $\mathrm{NO}_{2}^{-}-\mathrm{N}$ and to the reduction of DO to the "characteristic point" [23] (Fig. 4), which could be used as the control point for the nitritation process.

Thereafter, the influent $\mathrm{NH}_{4}^{+}-\mathrm{N}$ concentration was increased to $200 \mathrm{mg} / \mathrm{L}$. To maintain the nitritation

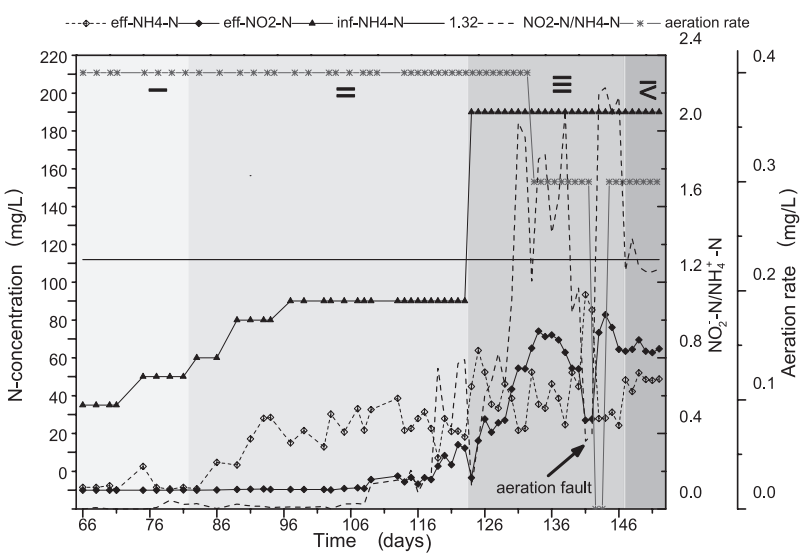

Fig. 3. Variations in influent/effluent concentrations of $\mathrm{NH}_{4}^{+}-\mathrm{N}$, $\mathrm{NO}_{2}^{-}-\mathrm{N}, \mathrm{NO}_{2}^{-}-\mathrm{N} / \mathrm{NH}_{4}^{+}-\mathrm{N}$ and aeration rate in the nitritation process. reaction, during stage III (Day 123-148) the aeration rate was reduced from 0.4 to $0.3 \mathrm{~L} / \mathrm{min}$, and nitrite nitrogen started accumulating rapidly in the system, reaching $86.2 \mathrm{mg} / \mathrm{L}$. During Day 142-143, due to aeration failure, the aeration rate of the system was reduced to zero, nitritation was seriously inhibited, and the $\mathrm{NO}_{2}^{-}-\mathrm{N}$ concentration dropped sharply. After troubleshooting the aeration failure, the aeration rate resumed at $0.3 \mathrm{~L} / \mathrm{min}$, and the $\mathrm{NO}_{2}^{-}-\mathrm{N}$ accumulation rate increased and stabilized at $50 \%$. After 148 days, the $\mathrm{NO}_{2}^{-}-\mathrm{N} / \mathrm{NH}_{4}{ }^{+} \mathrm{N}$ ratio of the system stabilized at 1.32 (Stage IV), providing the foundation for subsequent coupling with anammox.

As shown in Fig. 3, during the whole nitritation stage, the amount of accumulated $\mathrm{NO}_{2}^{-}-\mathrm{N}$ slowly increased as nitrogen loading rate (NLR) increased. During the late phase, due to denitrification in the reactor, the amount of accumulated $\mathrm{NO}_{2}^{-}-\mathrm{N}$ declined. Afterward, as NLR continued to increase, the aeration rate and aeration time were adjusted and the AOB became the dominant microflora. The conversion rate of $\mathrm{NH}_{4}^{+}-\mathrm{N}$ to $\mathrm{NO}_{2}^{-}-\mathrm{N}$ reached $95 \%$ on Day 142 . This finding is in full agreement with the results of a study of single-stage nitrogen removal in granular sludge, where NOB repression was also related to the residual ammonium concentration [14].

In addition, alkaline conditions facilitated the formation of FA, inhibited NOB activity by reducing the needed substrate, and provided a substrate for AOB [24]. The particular $\mathrm{pH}$ conditions also imposed a considerable direct effect on microorganisms. Optimal growth occurred at $\mathrm{pH}$ 7.0-8.5 for $\mathrm{AOB}$ and at $\mathrm{pH}$ 6.0-7.5 for NOB. At high $\mathrm{pH}, \mathrm{AOB}$ had greater activity than did NOB, leading to selection for nitritation reactions rather than nitration reactions. In contrast, the nitritation reaction system could be destroyed by low $\mathrm{pH}$. Figure 4 shows that if alkalinity were insufficient, the $\mathrm{NH}_{4}^{+}-\mathrm{N}$ was almost completely oxidized at $135 \mathrm{~min}$, and the $\mathrm{pH}$ value started to increase afterward.

In consideration of the corresponding DO changes, $\mathrm{pH}$ and DO were used as parameters to control the reaction time, and the nitritation process was controlled by changes in initial alkalinity and DO level during the reaction. Therefore, adequate alkalinity and a rational oxygen supply mode did not inhibit the nitration reaction rate, and facilitated the establishment of a stable control process for nitritation.

\section{Denitrification Performance of the CANON System}

\section{Start-up and Stable Operation}

During the startup stage of the nitritation process, the activity of NOB was inhibited and AOB continuously grew and reproduced. This was accomplished by enabling AOB and NOB to have different properties by manipulating various factors, such as DO, pH, COD, and FA. During the initial stage of the autotrophic nitrogen-removal process there was a small number of AAOBs in the system. Because the doubling time of $\mathrm{AOB}$ is more than 10 times 


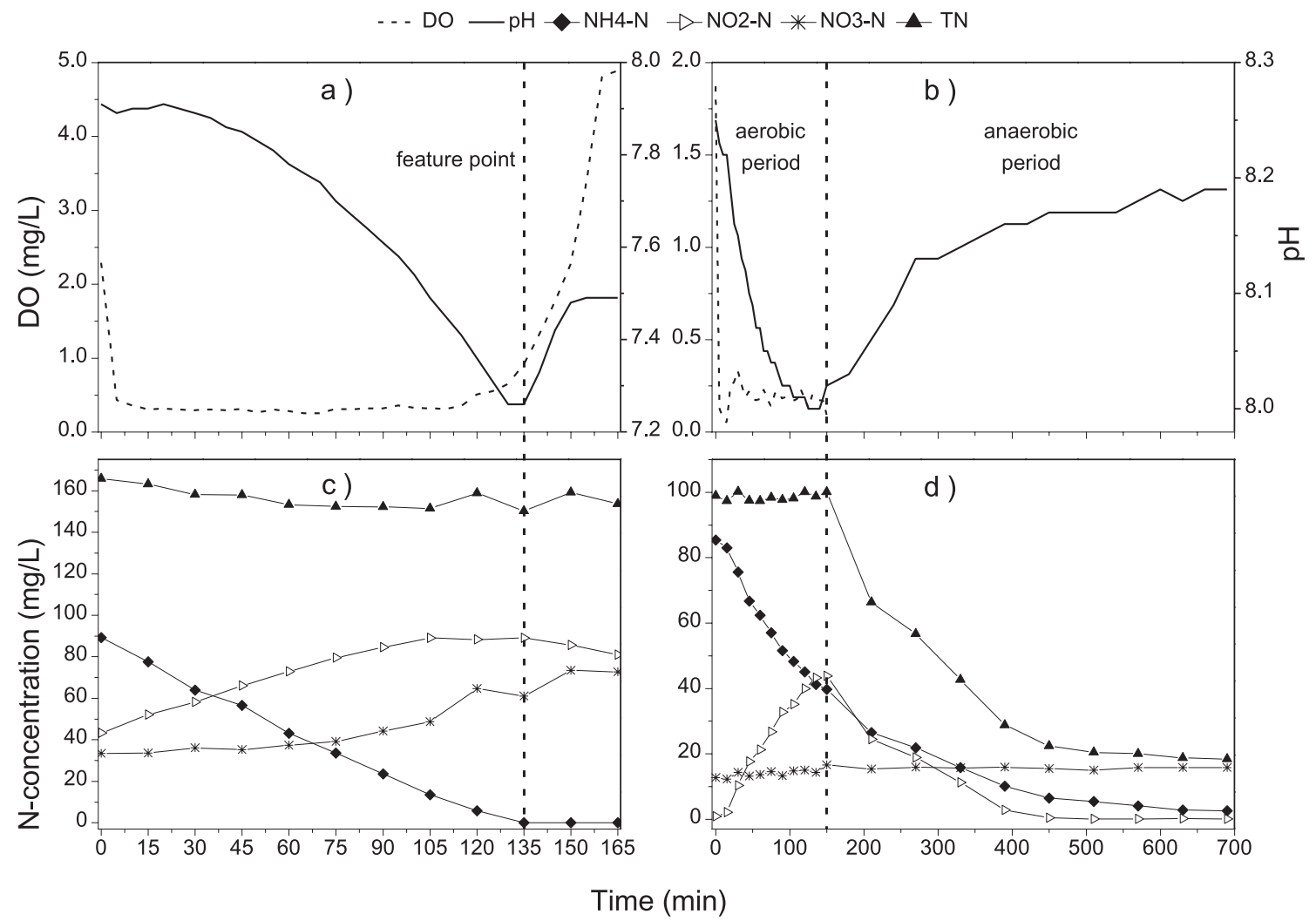

Fig. 4. Time course of parameters and substrates measured in two experimental phases: (a-c) nitritation regulation and (b-d) autotrophic nitrogen removal.

that of AAOB, the HRT was extended from 6 to $24 \mathrm{~h}$, and $4 \mathrm{mg} / \mathrm{L} \mathrm{N}_{2} \mathrm{H}_{4}$ was added as an intermediate product for stimulating the AAOB growth. These actions led to enhanced anammox [25] and rapid AAOB enrichment.

During Days 161-218 (Stage II), the nitrogen removal efficiency of the system gradually increased to $75.8 \%$ as a consequence of AAOB enrichment. The aeration time was extended from 130 to 145 min on Day 220 to ensure that $\mathrm{NO}_{2}-\mathrm{N}$ formation demand was met for the anammox

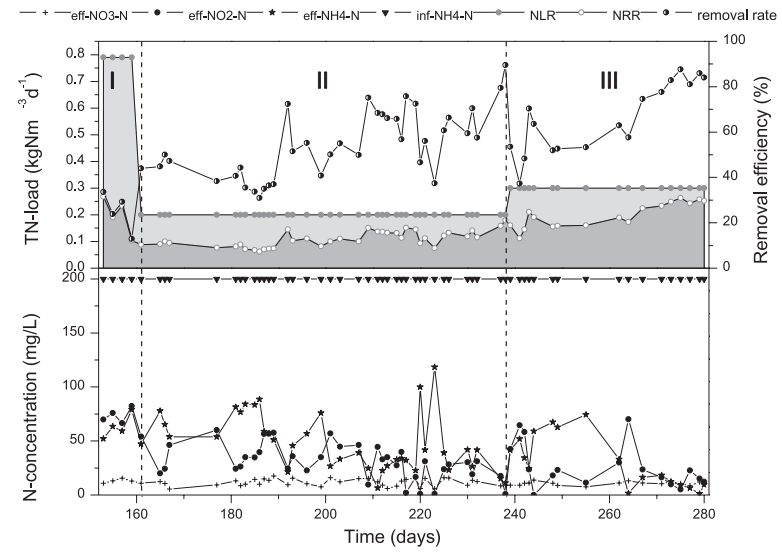

Fig. 5. Variation of nitrogen loading rate (NLR), nitrogen removal rate (NRR), removal efficiency, and $\mathrm{N}$ concentration of the autotrophic nitrogen removal process. process. Accordingly, the effluent $\mathrm{NH}_{4}^{+}-\mathrm{N}$ concentration decreased rapidly, which allowed the nitrogen removal efficiency and the nitrogen removal rate (NRR) to increase to $79.5 \%$ and $0.18 \mathrm{kgN} /\left(\mathrm{m}^{3} \cdot \mathrm{d}\right)$, respectively (Fig. 5).

To increase the hydraulic loading of the system, during Stage III the HRT was shortened to $12 \mathrm{~h}$ and the anaerobic reaction time was shortened. After this, the conversion rate of $\mathrm{NH}_{4}^{+}-\mathrm{N}$ and total nitrogen removal efficiency decreased. Thereafter, $\mathrm{NH}_{4}^{+}-\mathrm{N}$ gradually accumulated in the reactor, AAOB activity declined, and the total nitrogen removal rate fell to $37.2 \%$. When the aeration time was increased to $150 \mathrm{~min}$, the system gradually resumed its nitrogen removal performance. The nitrogen removal loading and total nitrogen removal rate were stabilized at $0.26 \mathrm{kgN} /\left(\mathrm{m}^{3} \cdot \mathrm{d}\right)$ and $84.3 \%$, respectively; higher than the total nitrogen removal rate of $74.4 \pm 7.1 \%$ and $72 \pm 9 \%$ obtained by C.M. Castro-Barros et al. [1] and Peili Lu et al. [26] with different types of reactors and conditions.

\section{Performance of a Typical Cycle}

Different reactors have different DO demands for startup and operation of the CANON process. The DO level in an SBR reactor is normally maintained at 0.5-0.8 mg/L. Helmer-Madhok et al. [27] found that when DO was $0-0.7 \mathrm{mg} / \mathrm{L}$, DO was positively correlated with the autotrophic nitrogen removal efficiency, and a further increase in DO level would destroy the system. Li et al. 
[28] successfully cultured CANON granular sludge in the SBR reactor at a DO level of $0.3-0.5 \mathrm{mg} / \mathrm{L}$, and the TN removal efficiency reached $63.7 \%$. Figure 4 shows that the DO concentration ranged from 0.09 to $0.39 \mathrm{mg} / \mathrm{L}$ during the CANON process, with a mean value of $0.22 \mathrm{mg} / \mathrm{L}$. These are similar to the results for integrated anammox processes reported abroad.

Both $\mathrm{AOB}$ and $\mathrm{AAOB}$ required suitable alkalinity, and the distribution ratios of reaction substrates $\mathrm{NH}_{3}$ and $\mathrm{HNO}_{2}$ in the liquid phase were also influenced by $\mathrm{pH}$. Therefore, it is necessary to adjust the $\mathrm{pH}$ carefully to enhance anammox without compromising ammonium oxidation and thereby increase nitrogen removal performance. Based on previous studies of the effects of $\mathrm{pH}$ on the CANON process, it is preferable to keep $\mathrm{pH}$ at 8 [9, 29-30].

Fig. 4 shows the conversion status of substrates as well as changes in the $\mathrm{pH}$ and $\mathrm{DO}$ in the reaction system within a single cycle. The first $1.5 \mathrm{~h}$ of the cycle was the aerobic stage. At the end of aeration, the $\mathrm{NO}_{2}^{-}-\mathrm{N} / \mathrm{NH}_{4}{ }^{+} \mathrm{N}$ ratio was 1.11 , and $\mathrm{NO}_{3}^{-}-\mathrm{N}$ and $\mathrm{TN}$ concentrations remained almost unchanged. During the anaerobic stage, $\mathrm{pH}$ gradually increased to an extent that offset the amount of alkali consumed in the nitritation stage. This enabled the system to achieve partial acid-alkaline balance, and also reflected the resource-saving nature of the CANON process.

\section{Characterization of the Microbial Community}

During the late phase of acclimation, the absolute abundance of AOB was $7.4 \%$ at the nitritation stage (Fig. 6), indicating considerable enrichment of AOB compared with that in the initial seeding sludge (absolute abundance $0.87 \%$ ). The absolute abundance slightly decreased during the autotrophic nitrogen removal stage. The NOB had a high concentration in the seeding sludge, while it sharply decreased during the nitritation stage and further declined to its lowest level in the CANON stage. The DNF exhibited the same patterns of change as the NOB. The absolute

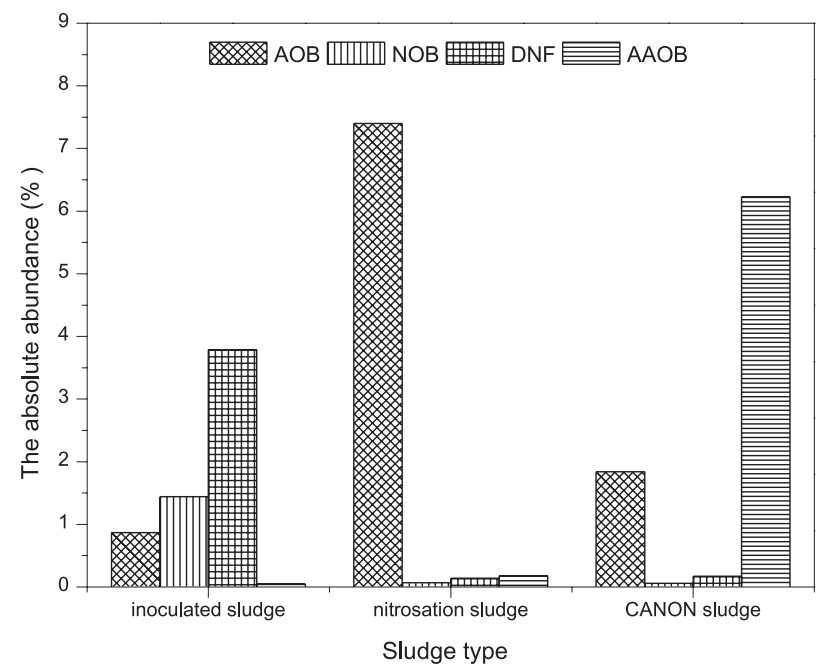

Fig. 6. Absolute abundance of functional bacteria in different stages. abundance of AAOB increased by 135-fold during the CANON stage, compared with that in the seeding sludge. The NOB was not completely eliminated, and the microflora in the system exhibited obvious structural changes. According to the results from previous domestic and international PCR studies [13], it can be seen that the AAOB were successfully enriched, and that AOB and AAOB became the predominant bacteria in the system.

When $\mathrm{AOB}$ and $\mathrm{AAOB}$ coexist in the system, $\mathrm{AOB}$ provides $\mathrm{AAOB}$ with reaction substrate and $\mathrm{AAOB}$ eliminates the substrate inhibition for AOB. However, they do compete for the same substrate when FA is insufficient in the system [31]. AOB is an aerobe while AAOB is an obligate anaerobe, the growth and metabolic processes of which are inhibited in the aerobic environment. Thus the relationship between the two bacteria is complicated. In a CANON system with adequate sludge granulation, the DO concentration gradient inside the granular sludge enabled the granular sludge to form a layered structure with aerobic exterior and anaerobic interior environments. This oxidative structure allowed AOB and NOB to coexist harmoniously in the same system.

\section{Conclusions}

Rapid startup of a nitritation-anammox process was achieved in a lab-scale SBR reactor with granular sludge. In the presence of ammonium, dissolved oxygen was an effective control parameter for suppressing the undesired NOB activity. AAOB were shown to grow in the CANON system and an organic balance between $\mathrm{AAOB}$ and $\mathrm{AOB}$ was achieved.

1. Nitrified sludge from a domestic wastewater treatment plant was inoculated and successfully granulated after 57 days of incubation. The NLR of the system was $0.08 \mathrm{kgN} /\left(\mathrm{m}^{3} \bullet \mathrm{d}\right)$, and nitrogen removal efficiency reached $90 \%$ or above. The sludge gradually changed to dark brown and more than $50 \%$ of the granules were larger than $1 \mathrm{~mm}$.

2. Partial nitritation was stably maintained long-term in a granular reactor with an average $\mathrm{NH}_{4}^{+}-\mathrm{N} / \mathrm{NO}_{2}{ }^{-} \mathrm{N}$ ratio of 1.32, when the AOB population had a higher affinity for DO than that of the NOB. The microbial structure and $\mathrm{NO}_{2}{ }^{-} \mathrm{N}$ accumulation rates were controlled using a strategy based on influent loads, aeration rate, and alkalinity.

3. Rapid AAOB enrichment and organic balance between $\mathrm{AAOB}$ and $\mathrm{AOB}$ can be achieved in a granular reactor under oxygen-limiting conditions. The nitrogen removal loading and total nitrogen removal rate were about $0.26 \mathrm{kgN} /\left(\mathrm{m}^{3} \bullet \mathrm{d}\right)$ and $84.3 \%$, respectively.

\section{Acknowledgements}

This research is supported by the Natural Science Fund of Hubei Province (grant No. 2014CFB285), 
the Wuhan Science and Technology Foundation (No. 2014060101010065) and the Wuhan Environmental Protection Scientific Research Projects (No. 20151h0035).

\section{References}

1. CASTRO-BARROS, C.M., DAELMAN, M.R.J., MAMPAEY, K.E. Effect of aeration regime on $\mathrm{N}_{2} \mathrm{O}$ emission from partial nitritation-anammox in a full-scale granular sludge reactor. Water Research 68 (1), 793, 2015.

2. DAVEREY A., SU S.H., HUANG Y.T., CHEN S.S., SUNG S.W., LIN J.G. Partial nitrification and anammox process: A method for high strength optoelectronic industrial wastewater treatment. Water Research 47 (9), 2919, 2013.

3. LACKNER S., GILBERT E.M., AGRAWAL S., KARST S.M., HORN H., NIELSEN P.H. Low Temperature Partial Nitritation/Anammox in a Moving Bed Biofilm Reactor Treating Low Strength Wastewater. Environmental Science Technology 48, 8784, 2014.

4. LIN J.G., DAVEREY A., CHEN Y.C., DUTTA K., HUANG Y.T. Start-up of simultaneous partial nitrification, anammox and denitrification (SNAD) process in sequencing batch biofilm reactor using novel biomass carriers. Bioresource Technology 190, 480, 2015.

5. CHAI L.Y., ALI M., MIN X.B., SONG Y.X., TANG C.J., WANG H.Y., YU C., YANG Z.H. Partial nitrification in an air-lift reactor with long-term feeding of increasing ammonium concentrations. Bioresource Technology 185, 134, 2015.

6. HISASHI S., RATHNAYAKE M.L.D., RATHNAYAKE M.O., ISHII S., SEGAWA, T., OKEBE S. Effects of dissolved oxygen and $\mathrm{pH}$ on nitrous oxide production rates in autotrophic partial nitrification granules. Bioresource Technology 197, 15, 2015.

7. ZHANG X.J., LI D., LIANG Y.H., ZENG H.P., HE Y.P., FAN D., ZHANG J. Start-up, influence factors, and the microbial characteristics of partial nitrification in membrane bioreactor. Desalination and Water Treatment 54 (3), 581, 2015.

8. PERSSON F., SULTANAR., SUAREZ M., HERMANSSON M., PLAZA E., WILEN B.M. Structure and composition of biofilm communities in a moving bed biofilm reactor for nitritation-anammox at low temperatures. Bioresource Technology 154, 264- 2014.

9. VAN DER MEER J.R., ZEHNDER A.J.B. Enrichment and characterization of an anammox bacterium from a rotating biological contactor treating ammonium-rich leachate. Archives of Microbiology 175 (3), 198, 2015.

10. LOTTI T., KLEEREBEZEM R., HU Z., KARTAL B., JETTEN M.S.M., VAN LOOSDRECHT M.S.M. Simultaneous partial nitritation and anammox at low temperature with granular sludge. Water Research 66 (3), 111, 2014.

11. LIU T., LI D., ZENG H.P., CHANG X.Y., ZHANG J. Microbial characteristics of a CANON reactor during the start-up period seeding conventional activated sludge. Water Science and Technology 67 (3), 635, 2013.

12. VLAEMINCK S.E., TERADA A., SMETS B.F., VAN DER LINDEN D., BOON N., VERSTRAETE W., CARBALLA $M$. Nitrogen removal from digested black water by one-stage partial nitritation and anammox. Environment Science and Technology 43, 5035, 2009.

13. GILBERT E.M., AGRAWAL S., KARST S.M., HORN H., NIELSEN P.H., LACKNER S. Low temperature partial
Nitritation/Anammox in a moving bed biofilm reactor treating low strength wastewater. Environmental Science \&Technology 48, 8784, 2014.

14. FERNÁNDEZ I., VÁZQUEZ-PADÍN J.R., MOSQUERACORRAL A., CAMPOS J.L., MÉNDEZ R. Biofilm and granular systems to improve ANAMMOX biomass retention. Biochemical Engineering Journal 42 (3), 308, 2008.

15. WEI D., DU B., ZHANG J., HU Z., LIANG S., LI Y.R. Composition of extracellular polymeric substances in a partial nitrification reactor treating high ammonia wastewater and nitrous oxide emission. Bioresource Technology 190, 474, 2015.

16. APHA. Standard Methods for the Examination for Water and Wastewater, $21^{\text {th }}$ Ed. American Public Health Association, Washington, DC., USA, 2005.

17. PENG Y.Z., WANG S.Y., MA B., WANG S.Y., ZHU G.B. Anaerobic ammonium oxidation in traditional municipal wastewater treatment plants with low-strength ammonium loading: Widespread but overlooked. Water Research 84, 66, 2015.

18. VÁZQUEZ-PADÍN J.R., MOSQUERA-CORRAL J.A., CAMPOS J.L., REVSBECH N.R. Microbial community distribution and activity dynamics of granular biomass in a CANON reactor. Water Research 44 (15), 4359, 2010.

19. ZHENG P., WANG L., XING Y.J., WEI L. YANG J., ABBAS G., LIU S., HE Z.F., ZHANG J.Q., ZHANG H.T., LU, H.F. Effect of particle size on the performance of autotrophic nitrogen removal in the granular sludge bed reactor and microbiological mechanisms. Bioresource Technology 157, 240, 2014.

20. FURUKAWA K., ZHANG L., YANG J.C. Stable and highrate nitrogen removal from reject water by partial nitrification and subsequent anammox. Bioscience and Bioengineering 110 (4), 441, 2010

21. PIJUAN M., WERNER U., YUAN Z.G. Reducing the startup time of aerobic granular sludge reactors through seeding floccular sludge with crushed aerobic granular aerobic granules. Water Research 45 (16), 5075, 2011.

22. ZHENG P., ABBAS G., WANG L., ZHANG J.P. Oxygen Transfer Characteristics in a Pilot-Scale Airlift InternalLoop Bioreactor for Simultaneous Partial Nitrification and Anaerobic Ammonia Oxidation. Environmental Engineering Science 31 (8), 453, 2014.

23. LI D., LIANG Y.H., ZENG H.P., ZHANG C.D., ZHANG J. Rapid start-up and microbial characteristics of partial nitrification granular sludge treating domestic sewage at room temperature. Bioresource Technology 196, 741, 2015.

24. DURAN U., DEL RIO A.V., CAMPOS J.L., MOSQUERACORRAL A., MENDEZ R. Enhanced ammonia removal at room temperature by $\mathrm{pH}$ controlled partial nitrification and subsequent anaerobic ammonium oxidation. Environmental Technology 35 (4), 383, 2014.

25. YAO Z.B., CAI Q., ZHANG D.J., XIAO P.Y., LU P.L. The enhancement of completely autotrophic nitrogen removal over nitrite (CANON) by $\mathrm{N}_{2} \mathrm{H}_{4}$ addition. Bioresource Technology 146, 591, 2013.

26. LU P.L., XIAO P.Y., ZHANG D.J. Effect of trace hydrazine addition on the functional bacterial community of a sequencing batch reactor performing completely autotrophic nitrogen removal over nitrite. Bioresource Technology 175, 216, 2015.

27. HELMER M.C., SCHMID M., FILIPOV E., GAUL T., HIPPEN A., ROSENWINKEL K.H., SEYFRIED C.F., WAGNER M., KUNST S. Deammonification in biofilm systems: population structure and function. Water Science and Technology 46 (1-2), 223, 2001. 
28. LI D., LIANG Y.H., ZHANG X.J., ZENG H.P., YANG Z., CUI S.M., ZHANG J. Stability and nitrite-oxidizing bacteria community structure in different high-rate CANON reactors. Bioresource Technology 175, 189, 2015.

29. LI K., FANG F., GUO J.S. Performance of one-stage autotrophic nitrogen removal in a biofilm reactor with low C/N ratio. Environmental Technology 36 (14), 1819, 2015.

30. XING B.S., JI Y.X., YANG G.F., CHEN H., NI W.M., JIN R.C. Start-up and stable operation of partial nitritation prior to ANAMMOX in an internal-loop airlift reactor. Separation and Purification Technology 120, 458, 2013.

31. LACKNER S., THOMA K., GILBERT E.M., GANDER W., SCHREFF D., HORN H. Start-up of a full-scale deammonification SBR-treating effluent from digested sludge dewatering. Water Science and Technology 71 (4), $553,2015$. 